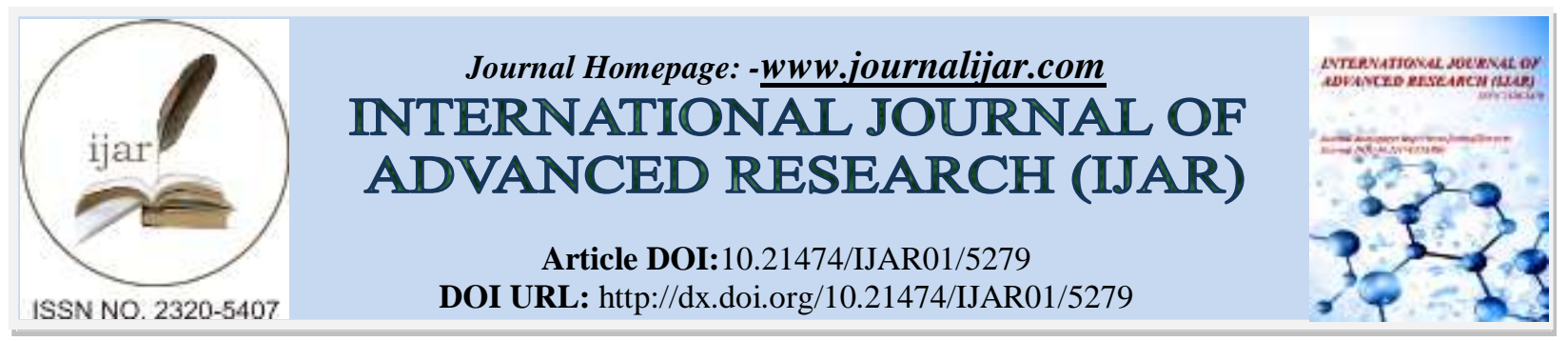

RESEARCH ARTICLE

\title{
RECONSTRUCTION OF PROCUREMENT OF GOODS AND SERVICES BY THE STATE-OWNED ENTERPRISE BASED ON JUSTICE VALUE.
}

\section{Sedyo Prayogo ${ }^{1}$, Gunarto ${ }^{2}$ and Jawade Hafidz ${ }^{3}$.}

Faculty of law universitas islam sultan agung semarang Indonesia.

\section{Manuscript Info}

Manuscript History

Received: 25 June 2017

Final Accepted: 27 July 2017

Published: August 2017

Keywords:-

Reconstruction, Procurement.State-

Owned Enterprises,Justice Value.

\begin{abstract}
This study aims to reconstruct thoughts or ideas based on the value of justice. On the methodology dimension. The approach used is hermeneutic and dialectical method to reach the truth. Findings, With the implementation of E-Procurement system is expected to be the right solution to the problems that occur in the procurement process of government goods and services. E-procurement is a system that utilizes information technology that includes values of transparency, efficiency, openness. In fact, E-Procurement still has weaknesses and obstacles in its implementation process, such as lack of financial support, there are some agencies and service providers more comfortable with the previous system (procurement of conventional goods and services.
\end{abstract}

Copy Right, IJAR, 2017,. All rights reserved.

\section{Introduction:-}

Procurement of goods and services for the benefit of the government is one tool to drive the wheels of the economy, therefore budget absorption through the procurement of goods and services is very important. However, no less important than that is the urgency of procurement implementation that is effective and efficient and economical to get maximum benefit from the use of budget.

There has been a lot of attention focused on various issues around the procurement of goods and services for the benefit of the government, partly because of the many irregularities in the planning, implementation, and supervision. Efforts to eradicate corruption especially in this area will only be effective if followed by prevention and early detection of irregularities. ${ }^{1}$

The reforms of 1998 brought about the discourse of democratization and change in various fields, and legal reform was one of the agendas to be implemented. But in reality until the 2014 Election the improvement in the legal field has not yet shown favorable results. As with the creation of various kinds of legislation, to prevent and regulate any actions that can have good and bad impacts in their implementation.

The legal subject in the procurement contract is the user of the goods and the goods provider. The user of the goods is the head of the office / work unit / project leader / project leader / user of the local budget / official who is equated

\footnotetext{
${ }^{1}$ Taufiequrachman Ruki, 2006, "Pengadaan Barang dan Jasa untuk Kepentingan Pemerintah", Paper at Seminar on Procurement of Goods and Services held by KPK and KPPU on August 23, 2006, Corruption Eradication Commission (KPK), Jakarta, p.1
} 
to the job owner responsible for the procurement of goods within the particular work / project environment. Provider is a business entity or an individual whose business activities is to provide goods. ${ }^{2}$

The object of this contract is the procurement activities of goods.

The notion of a public auction is a method of choosing a provider of goods / services that is done openly with the announcement widely through mass media and official announcement boards for people to see so that the broad community of interested and qualified ones can follow it.

State-Owned Enterprises (BUMN/BUMNs) under Article 1 Sub-Article 1 of Law Number 19 Year 2003 is a business entity which is wholly or partly owned by the state through direct participation derived from separated state assets.

The purpose of Ste BUMN synergy is to make the procurement process in a fast, flexible, competitive, efficient and effective without losing business momentum resulting in loss of the company. The apparently philosophical objectives and legal reasons apparently lead to two different conclusions, especially with regard to direct appointment. The Reign of President Soekarno has failed. In relation to that, what matters is how. ${ }^{3}$

In addition to, these reasons may deviate from the original intention, if the organizer in the field has no understanding of the intent and purpose of establishing the regulation. In fact, if there is a mistake in managing the BUMN, will result in a multiplied effect, both against the company in particular and the state losses in particular.

According to Article 1315 of the Civil Code, in general no one can bind himself on his own behalf or ask for a promise, but for himself. This principle is called the personality principle of an agreement. Binding is aimed at assuming duties or committing to do something, while asking for a promise, aimed at obtaining rights over something or being able to demand something. It is proper that the legal engagement which is born of a covenant only binds the people who make the covenant itself and do not bind others. An agreement only places the rights and obligations between the parties that make it. Other people are third parties who have nothing to do with the agreement. $^{4}$

Normally an agreement is reciprocal or bilateral. It means: a party which acquires the rights of the treaty, also accepts the obligations which are the reverse of the rights it obtains, and on the contrary a party which bears the obligations also obtains the rights which are regarded as the reverse of the obligations which Charged him. If that is not the case, that is, if the party obtaining the rights of the treaty is not burdened with the obligations as opposed to those rights, or if the party accepting the obligations does not acquire the rights as the reverse, such treaty It, is unilateral or one-sidedly. ${ }^{5}$

Based on the above description, the main question that will be answered regarding this research is can a reconstruction of procurement of goods and services implemented by BUMNs and the construction policy ideas be done based on the value of justice?

Method of Research:-

Research methods Descriptive Analitive used to describe the object or subject under investigation seen as it is. ${ }^{6}$ Paradigm ${ }^{7}$ used in this research is constructivism paradigm ${ }^{8}$, The paradigm that underlies this writing is the

${ }^{2}$ Salim HS, 2007, Perkembangan Hukum Kontrak di Luar KUH Perdata, Buku Satu, Raja Grafindo Persada, Jakarta, p. 259

${ }^{3}$ Elvira Fitriyani Pakpahan, Tommy Leonard, Heriyanti, LEGAL ANALYSIS ON BOND ISSUANCE OF THE RETAIL (ORI), International Journal of Business, Economics and Law, Vol. 11, Issue 4 (Dec.) ISSN 2289-1552, p. 26

${ }^{4}$ Subekti, 1982, Aneka Perjanjian, Alumni, Bandung, p. 29.

${ }^{5}$ Ibid, p. 30.

${ }^{6}$ Rahmat Basuki, Gunarto, Anis Masdurohatun, The ideal role of welfare state in the concept of health social insurance of BPJS based on justice values, International Journal of Multidisciplinary Research and DevelopmentOnline ISSN: 2349-4182, Print ISSN: 2349-5979, Impact Factor: RJIF

5.72www.allsubjectjournal.comVolume 4; Issue 7; July 2017; p. 183 
paradigm of constructivism, because this research is intended to produce a reconstruction of thought or idea based on the value of justice. In the dimension of methodology ${ }^{9}$ the approach used is hermeneutic and dialectical method to reach the truth. This research uses primary data, ie data obtained directly from the source, either through interviews, observations or reports in the form of unofficial documents which are then processed by the researcher, and secondary data, that is data taken from library materials consisting of 3 ( Three) sources of legal materials namely primary, secondary and tertiary legal materials. Primary data, ie data obtained directly from the source, either through interviews, observations and reports in the form of unofficial documents that are then processed by researchers, and secondary data, ie data taken from the library material consisting of 3 (three) sources of materials Law namely primary, secondary and tertiary legal materials.

Primary data collection technique is done by observation and in-depth interviews with key informants that have been determined by researchers based on research characteristics. ${ }^{10}$ Respondents to be interviewed are contractor and Public Works Department. While secondary data collection, conducted by literature study (documentation) is a series of efforts to obtain data by reading, reviewing, classifying and doing an understanding of legal materials in the form of regulations, the literature that is relevant to the issues raised. ${ }^{11}$ The research approach applied to the problems in this research using sociological juridical approach (socio-legal study), which in this study conducted an assessment of the rules, norms prevailing in society and directing research to Legal function in the community, related to positive national law, prevailing in Indonesia. ${ }^{12}$

\section{Research Result and Discussion:-}

Based on the implementation of the interview results by the author. The regulation concerning Procurement of Goods and Services for State-Owned Enterprises (BUMN) in effect at present is:

${ }^{7}$ Paradigm is defined as a frame of reference or perspective that became the basis of the belief or foothold of a theory. Paradigm is a foothold in seeing a reality, how do we see things, what is considered a problem, what methods used to solve. Thomas Kuhn, The Structures of Scientific Revolution, in Widodo Dwi Putro, 2011. Kritik Terhadap Paradigma Positivisme Hukum, Genta Publishing, Jogjakarta, , P. 2. While Guba defines that the paradigm is the basic system concerning the fundamental belief in the world of the object studied (Worldwiew) which is a guide for researchers. Guba and Lincoln, 1944, Computing Paradigms in Qualitative Research, Handsbook of Qualitative Research, London, Sage Publication, p. 105. Paradigms help formulate what to learn, what issues to answer, how to answer them, and what rules to follow in interpreting the information gathered in order to address them. George Ritzer, Sociology: A multiple paradigm of science, translated by Ali Mandan, SSosiologi Ilmu Pengetahuan Berparadigma Ganda, Rajawali Pers, Jakarta, 2011. P. 77. Paradigm is a set of beliefs or basic beliefs that require a person to act in everyday life as well as in scientific research. Agus Salim, 2011, Teori dan Paradigma Penelitian Sosial (Dari Densin Guba dan Penerapannya), PT. Tiara Wacana, Jogjakarta. P. 33, see also Liek Winarjo, who states that the paradigm is "ondering belief frame work", which means the basic assumptions the scientist believes and determines the way he perceives the symptoms he examines. It can include codes of ethics, as well as worldviews that influence the way of thought and behavior of scientists in science. Liek Wilarjo, Loc.Cit.

${ }^{8}$ Egon G. Guba dan Yvona S, Lincoln, 1994, Handbook of Qualitative Research, London \& New Delhi : Sage Publications International Education and Professional Publisser, p. 100

${ }^{9}$ Methodology focuses on how we gain knowledge of the world. Norman and Yvonna S. Lincolm. Op.cit. P. 123 while Agus Salim states that in the methodological dimension a scientist must answer the question: how is one used in discovering the truth of a science. Agus Salim. Op.cit. P. 35

${ }^{10}$ Lexy J, moleong, Metodologi Penelitian Kualitatif, Edisi Revisi, Bandung: PT Remaja Rosdakarya, 2010, p. 148

${ }^{11}$ Soerjono soekanto dan Sri Mamudji, PenelitianHukumNormaif,SuatuPengantar Singkat,Jakarta:PTRajaGrafindoPersada,2003,p.25

${ }^{12}$ Abdul Kholik. S. H. M.SI, Deddy Ismatullah. S. H. M.HUM \& Widayati. S. H. M.H, THE AUTHORITY DISPUTE OF STATE INSTITUTIONS IN THE IMPLEMENTATIONOF BICAMERAL SYSTEM IN INDONESIA (Study on Disputes between the House of Representatives (Dewanperwakilan Rakyat)-Republic of Indonesia and the House of Representatives-Republic of Indonesia in the Implementation of Legislative Function)International Journal of Political Science, Lawand International Relations (IJPSLIR)ISSN (P): 2278-8832; ISSN (E): 22788840Vol. 7, Issue 4, Aug 2017, p. 37 
1. If the budget is entirely derived from DIPAK / L / I shall be in accordance with the provisions of Presidential Regulation No. 54 of 2010.

2. If the budget is derived from the operational cost of the BUMNs listed in the RKAP either from its business income or from government equity which is the result of procurement of goods / services as separated state assets then use the guideline of the use of goods / services based on the BUMN's Decree on Procurement of Goods / Services (SOP- PB / J SOE concerned). (Vide PP 45 Year 2005 and Performing SOE Per-05 / MBU / 2008).

Regarding the regulation on Procurement of Goods / Services for BUMNs is a different arrangement with the Procurement of Goods / Services by the Government in general, according to the Secretariat of the Ministry of BUMNs ${ }^{13}$ the similarity lies in the principle of Procurement of Goods / Services ie Efficient, Effective, Open, Transparent, Fair, Accountable, Competent. Procurement of BUMN goods / services is private non-public procurement, BUMN is one of the government-owned business entities that become the source of state income. BUMNs are given authority in managing their business, including in the procurement of goods / services whose purpose is to accelerate business services to customers and profit-oriented. But SOE finance is state finance (Act No. 1 of 2004), so the loss of state finance is a state financial loss, if caused by unlawful acts or misuse of authority, remain subject to sanction of corruption (Vide: Articles 2 and 3 of Law 31 Year 1999 jo Act 20 of 2001). So in the Procurement of Goods / Services SOE directors are authorized to establish their own guidelines (SOP PBJ SOE).

Requirements for procurement of goods / services for BUMNs are equivalent to procurement of goods / services of the Government because the perpetrator is a Civil Business Entity / Individual governed by regulations in their respective fields (Article 19 of Perpres 54 of 2010).

In general the pattern of supervision in the procurement of goods / services BUMN as follows :

1. Internally by the Waskat system applied by management using the risk management system by the relevant BUMN (ISO 31000 reference)

2. The supervisory system follows the SPIP (Corporate Internal Control System) that adopts SPIP in Government (Vide: PP 60 Year 2008)

3. Supervision by the SPI Unit (Internal Control Unit)

4. Supervision by the Government Auditor both BPK and BPKP

5. Supervision by the Independent Auditor is usually done by KAP (Public Accounting Firm)

Follow-up on the results of supervision in the Procurement of Goods / Services for BUMNs that indicated irregularities that happened, namely :

In the form of check and balances and follow-up (T3) based on Report of Inspection and Supervision Result (LHP) by Board of Directors based on Supervisor / Inspector's Recommendation if supervision is done internally by Waskat system applied by management using risk management system by the BUMN concerned, The supervisory system follows SPIP (Corporate Internal Control System) which adopts SPIP in Government, Supervision by SPI Unit (Internal Audit Unit) and Supervision by Independent Auditor is usually done by KAP (Public Accounting Firm).

If the supervision by BPKP or BPK is based on Recommendation by BPKP or BPK Auditor unless the examination is PDTT (Checking with Specific Purposes) because there is an Indication of Distribution in Procurement of StateOwned Goods / Services which lead to the financial loss of the State (Vide: Law Number 15 of 2004).

The regulation of irregularities that occurred in the Procurement of BUMN goods / services can be distinguished in 3 categories :

a. Faulted procedures, repeated auctions or repeated evaluations

b. Abuse of authority: Auctions canceled or foiled and sanctions on the party who committed abuse of authority

c. The existence of manipulation; the auction is canceled and the procurement program for the work is canceled or removed from RKAP and sanctioning the perpetrators of this manipulation (Auction Committee / Pokja ULP BUMN and / or Partner)

he way of regulating it is by including it in the articles of the BUMN Regulation on the Procurement of Goods / Services in the relevant BUMNs, especially the provision of decline opportunities or reports to the APH or the legal

${ }^{13}$ Interview with BUMN secretary office, on 6 September 2016 
rights in the Administrative Court on the results of the tender / election process, including the supervision by the public.

According to thethe secretary office of BUMNs,${ }^{14}$ which is authorized to conduct an investigation, the investigation into criminal acts occurred in the process of Procurement of Goods / Services of BUMNs is the Police and or Prosecutor Office in accordance with the provisions given by the Law. For follow-up to errors in the process of Procurement of goods / Services BUMN certainly can not necessarily be done, as it must be seen its mens rea first, whether included in category of Ultimum Remedium or Primum Remedium. If including Ultimum Remedium then the Action given is by Administrative sanction, and then civil and penal law as a last resort and only if they deliberately act against the law (Vide Act 1 of 2004 Article 1 Number 22).

As it is known that the scope of the enactment of Presidential Regulation Number 54 Year 2010 stated in Article 2 paragraph (1) letter b regarding the Procurement of Goods / Services for investment in the environment of Bank Indonesia, State-Owned Legal Entities and State-Owned Enterprises operational fund are wholly or partially charged to APBN / APBD.

According to the Secretariat of the Ministry of BUMNs ${ }^{15}$ the constraints faced by BUMNs in the process of Procurement of Goods / Services in BUMN are :-

1. When the Law Enforcement Officers does not / understand the Implementation of Procurement of Goods / Services.

2. Unprofessionally arranged resulting in multiple interpretations in the implementation, consequently the process of procurement of goods / services of BUMNs become unaccountable and could potentially cause losses of state finances because the procurement procedures does not implement the principle of competing well.

In Ramli Samsul's book, Procurement of goods and services starts from the planning of needs, the preparation of the procurement plan, the selection of providers, the signing of contracts, the execution and control of contracts, to the receipt of goods and services. ${ }^{16}$

Procurement aims to obtain goods or objects. Goods are any object, tangible or intangible, mobile or immovable, which may be traded, used, or utilized by the user of goods / services comprising of input, process, and / or output. ${ }^{17}$ State-Owned Enterprises (BUMNs) which are all or most of their capital derived from separated state assets, are one of the economic actors in the national economic system, in addition to private businesses and cooperatives. In carrying out its business activities, BUMNs, private and cooperatives carry out the role of mutual support based on economic democracy. ${ }^{18}$

Implementation of the role of BUMN is realized in business activities in almost all economic sectors, such as agriculture, fishery, plantation, forestry, manufacturing, mining, finance, post and telecommunications, transportation, electricity, industry and trade, and construction. ${ }^{19}$

Optimizing the role of BUMNs and able to maintain their existence in the development of an increasingly open and competitive world economy, BUMNs need to grow the corporate culture and professionalism, among others, through improvements management and supervision. Management and supervision of BUMNs should be based on good corporate governance principles. Increased efficiency and productivity of BUMNs should be done through restructuring and privatization measures. ${ }^{20}$

National Development is very many types and kinds, one form of realization of sustainable development of public facilities and infrastructure projects.For example the construction of roads, bridges, offices, construction of public

\footnotetext{
${ }^{14}$ Interview with BUMN Office secretary, on13January 2017

${ }^{15}$ Interview with BUMN Office secretary, on23 February 2017

${ }^{16}$ Samsul Ramli, 2014, Buku Bacaan Wajib Sertifikasi Ahli Pengadaan Barang/Jasa Pemerintah, Penyunting, Zulfa Simatur, Cet. 1, Visimedia, Jakarta, p. 2

${ }^{17} \mathrm{Ibid}$, p. 6

${ }^{18}$ Mulhadi, 2006, Hukum Perusahaan: Bentuk-Bentuk Badan Usaha di Indonesia, Ghalia Indonesia, Jakarta, p.142

${ }^{19} \mathrm{Ibid}$, p. 5

${ }^{20}$ Ibid, p. 144
} 
housing, and much more. National development can not be separated from various layers such as contractors, assigners, architect, and so forth. And also need to be noted is the sophisticated equipment needed in the implementation of such development.

Furthermore, every implementation of the procurement of goods and services is regulated starting from President Decree no. 80 of 2003 on goods and services subsequently superseded by Presidential Regulation no. 54 of 2010 which refined the Regulation of the President of the Republic of Indonesia no. 70 of 2012 on the Second Amendment to Presidential Regulation no. 54 of 2010 concerning Procurement of Government Goods / Services. Presidential Regulation No.70 Year 2012 Article 1 Providing the definition of Procurement of Goods / Services is the activity to obtain Goods / Services by the Ministry / Institution / Work Unit of Regional Devices / Institutions whose process starts from the planning of needs until the completion of all activities to obtain Goods / Services. ${ }^{21}$ The contract of employment is an agreement between the party who engages the employer and the employee, where the The first party wants a result from second's party's work, with compensation in the form of payment of a lump sum of money as the price of the contract. ${ }^{22}$

In accordance to the government policy to utilize information technology in order to accelerate the implementation of state expenditure, Presidential Regulation No. 4 of 2015 allows the process of procurement of goods / services government to be done more simply. Presidential regulation No. 4 of 2015 not only requires that the procurement process of government goods / services to be done electronically through E-Tendering and E-Purchasing, but also to simplify the requirements that the goods / service providers must follow in E-Tendering. This Ease and simplification can be seen from several articles in presidential regulation No. 4 of 2015.

Procurement of goods / services funded by the State / Local Budget (APBN / D), are generally increasing from year to year. Similarly, the components of APBN / D expenditure in the form of capital expenditure (investment) / direct expenditure, the implementation is done through the procurement of goods / services. To realize capital expenditures / directly through the procurement of goods and services involving various parties, ie users, are those who need goods / services, and providers of goods / services, are those carrying out work or services, which are made on request or by an official order Or contract from the user. ${ }^{23}$

Procurement of goods / services is essentially an effort of the user to obtain or realize the goods / services he wants, to then each party must be subjected to the ethics and norms / regulations that apply to the procurement process of goods / services. ${ }^{24}$ The determination to select the provider of goods / services is done by Public Auctions, Limited Auctions, Direct Selection, and Direct Appointment. Of the four methods, it is determined that the Public Auction method is the main principle used in the implementation of procurement of goods / services. Of the four methods in general that many implemented by government agencies, is to use the way of direct appointment and by way of public auction.

Bureau of Equipment and Asset Management of The Regional Secretariat is a party that plays an important role in the procurement process of goods and services at the provincial level, whether in the early stages where the auction organizers work until the final stage of the procurement of goods and services.

The existence of the Goods and Services Procurement Agreement emerges as part of the development process which is a very significant government work program, to spur the growth and development of the national potential. Development is identical with the development of public facilities and infrastructure by the government that is intended for public interest and government administration. Basically development is a continuous process that leads to a gradual shift that covers all aspects of life toward improving people's lives.

${ }^{21}$ Republik Indonesia, 2010, Perpres No. 70 Tahun 2012 tentang Pengadaan Barang/Jasa Pemerintah, Fokusmedia, Jakarta, p. 2

${ }^{22}$ R. Subekti, 1995, Aneka Perjanjian, Cetakan Kesepuluh, PT. Citra Aditya Bakti, Bandung, p. 58

23 Agus Kartasasmita, 2006, "Pengadaan Barang/Jasa Pemerintah Menurut Pelaku Usaha" Makalah Seminar Nasional Seminar Nasional dengan Tema "Upaya Perbaikan Sistim Penyelenggaraan Barang / Jasa Pemerintah. Jakarta, p. 4

${ }^{24} \mathrm{Abu}$ Samman Lubis. "Aspek Hukum dalam Pengadaan Barang dan Jasa Pemerintah" makalah.http://www.bppk.depkeu.go.id/bdk/pontianak/index.php?option=com_content\&view $\quad$ article $\& i d=60$ :aspek-hukum-, date access 29 September 2016 
Based on the foregoing description, it can be concluded that the Government Procurement Agreement may be qualified as a Sale and Purchase Agreement as written in Book III of Part V of the Indonesian's Civil Code, and as such it may also be classified as a Names / Special Agreement / Nominate. ${ }^{25}$

Government procurement agreements may also be referred to as Standard Sale and Purchase Agreements. It is also characterized as mutual agreement, because each has rights and obligations. Also as consensual agreement because it was born in the presence of an agreement. As an agreement on expenses because it gives the burden to each party in the form of giving or doing something. And also as a formal agreement, because of the agreement if it has fulfilled certain formalities as well as certain forms prescribed by law.

Standard or standard agreement is born as a form of business development and demands. Standard contracts have been widely applied in the business world such as banking, consumer finance institutions, and various other forms of business. Standard or standard contracts are seen as more efficient in terms of time and cost. ${ }^{26}$

According to secretary office of BUMN,${ }^{27}$ in Law Enforcement a corruption case of Procurement of Goods / Services that occurs is the existence of public pressure or NGO's.

Another result of e-Procurement is minimization / avoidance of face-to-face opportunities between suppliers of goods and services with procurement committees and e-Procurement system managers. The system in eProcurement is created to avoid the face-to-face opportunities between prospective providers of goods and services with the procurement committee, because face-to-face that is the main factor of irregularities in the procurement process of goods and services. With most systems being done online (including aanwijzing and clarification) there is no longer a chance to meet each other between prospective providers / suppliers and procurement committees. The meeting is usually in the framework of negotiations related to the procurement process of goods and services with the purpose of their benefit but to the detriment of state finances. The e-Procurement system does not recognize the bidding process together at one time and in the same room is known as the bidding room, for consideration of: ${ }^{28}$

1. The likelihood of participants coming late because the transportation system in the country is still fall behind. Better participants can bid anytime and from anywhere through the internet as long as it has not exceeded the deadline of the offer;

2. If there is a meeting between the procurement committee and among the auction participants in the bidding room, then the chances of unfair play will still be open.

To overcome this came e-Procurement which is the process of procurement of goods / services online. EProcurement or electronic auction is a process of procurement of goods / services within the scope of government that use information and communication technology tools in every process and step. Currently, e-Procurement is one of the best approaches to prevent irregularities in procurement of government goods / services. With e-Procurement opportunities for direct contact between suppliers / goods and procurement committees are becoming smaller, more transparent, more time-efficient and cost-effective and easy to carry out financial accountability.

In the implementation of E-Procurement in the work unit within the Ministry of Public Works, there are still some obstacles, such as :

1. E-Procurement implemented within the Ministry of Public Works has not become a maximum control function. Still face to face in the process of procurement of goods and services with E-Procurement system, making the still-open potential for cheating.

2. The existing E-Procurement within the Ministry of Public Works does not have inter-agency data integration design, including data integration to the Directorate General of Taxes and Banking. This is required as a control of the tax report for auction participants when registering and when appointed as the winner of the auction.

3. The absence of design concept of E-Procurement application development in the Ministry of Public Works to meet the needs and guarantees of applications in the future.

${ }^{25}$ Caryos. "Tinjauan Perjanjian Pengadaan Barang / Jasa Pemerintah Dalam Hukum Perjanjian Indonesia". http://caryos.blogspot.com/2008/03/tinjauan-perjanjian-pengadaan-barang.html, date access 29 September 2016

${ }^{26}$ Shidarta, 2000, Hukum Perlindungan Konsumen Indonesia, Terbitan Pertama, Grasindo, Jakarta, hlm. 29

${ }^{27}$ Wawancara dengan Sekretariat Kementerian BUMN, pada tanggal 6 September 2016

${ }^{28}$ Much. Nurachmad, 2011, Buku Pintar Pengadaan Barang/Jasa Pemerintah, Transmedia Perkasa, Jakarta, hlm. $140-141$ 
In addition to the use of e-procurement in the procurement process of government goods and services, the reconstruction of procurement of goods and services for BUMNs based on the value of justice should also be established as clearance agency that is an institution that issued certification for the quality of the work after the completion of the work of the chartering. The existing clearance agency is a court ruling. Service providers who indicate a mistake or misappropriation in the execution of procurement work are usually more likely to wait for civil litigation from the budget user, because if the provider of goods and services pay or repay the underutilized project or the unfinished project will be sued as having committed a corruption.

\section{Conclusion:-}

The implementation of E-Procurement system is expected to be the right solution to the problems that occur in the procurement process of government goods and services. E-procurement is a system that utilizes information technology which includes values of transparency, efficiency, openness. In reality E-Procurement still has weaknesses and obstacles in its implementation process, such as lack of financial support, there are few institutions and service providers more comfortable with the previous system (conventional procurement of goods and services), lack of support from top management, lack of skills And knowledge of E-Procurement, as well as the system's security guarantees.

In addition to the use of e-procurement in the procurement process of government goods and services, the reconstruction of procurement of goods and services carried out by SOEs based on the value of justice should also be established a clearance agency that is an institution that issued certification for the quality of the work after the completion of the chartering work.

\section{References:-}

Books:-

1. Abu Samman Lubis. "Aspek Hukum dalam Pengadaan Barang dan Jasa Pemerintah" makalah.http://www.bppk.depkeu.go.id/bdk/pontianak/index.php?option=com_content\&view $\quad=$ article \&id=60:aspek-hukum-, diakses tanggal 29 September 2016

2. Agus Kartasasmita, 2006, "Pengadaan Barang/Jasa Pemerintah Menurut Pelaku Usaha" Makalah Seminar Nasional Seminar Nasional dengan Tema "Upaya Perbaikan Sistim Penyelenggaraan Barang / Jasa Pemerintah. Jakarta

3. Caryos. "Tinjauan Perjanjian Pengadaan Barang / Jasa Pemerintah Dalam Hukum Perjanjian Indonesia". http://caryos.blogspot.com/2008/03/tinjauan-perjanjian-pengadaan-barang.html, diakses tanggal 29 September 2016

4. Egon G. Guba dan Yvona S, Lincoln, , Handbook of Qualitative Research, London \& New Delhi : Sage Publications International Education and Professional Publisser. 1994

5. Lexy J, moleong, Metodologi Penelitian Kualitatif, Edisi Revisi, Bandung: PT Remaja Rosdakarya, 2010

6. Much. Nurachmad, 2011, Buku Pintar Pengadaan Barang/Jasa Pemerintah, Transmedia Perkasa, Jakarta

7. Mulhadi, 2006, Hukum Perusahaan: Bentuk-Bentuk Badan Usaha di Indonesia, Ghalia Indonesia, Jakarta

8. R. Subekti, 1995, Aneka Perjanjian, Cetakan Kesepuluh, PT. Citra Aditya Bakti, Bandung

9. Republik Indonesia, 2010, Perpres No. 70 Tahun 2012 tentang Pengadaan Barang/Jasa Pemerintah, Fokusmedia, Jakarta

10. Salim HS, 2007, Perkembangan Hukum Kontrak di Luar KUH Perdata, Buku Satu, Raja Grafindo Persada, Jakarta

11. Samsul Ramli, 2014, Buku Bacaan Wajib Sertifikasi Ahli Pengadaan Barang/Jasa Pemerintah, Penyunting, Zulfa Simatur, Cet. 1, Visimedia, Jakarta

12. Shidarta, 2000, Hukum Perlindungan Konsumen Indonesia, Terbitan Pertama, Grasindo, Jakarta

13. Soerjono soekanto dan Sri Mamudji, PenelitianHukumNormaif,SuatuPengantar Singkat,Jakarta:PTRajaGrafindoPersada,2003

14. Subekti, 1982, Aneka Perjanjian, Alumni, Bandung

15. Taufiequrachman Ruki, 2006, "Pengadaan Barang dan Jasa untuk Kepentingan Pemerintah", Makalah pada Seminar Pengadaan Barang dan Jasa yang diselenggarakan oleh KPK dan KPPU pada tanggal 23 Agustus 2006, Komisi Pemberantasan Korupsi (KPK), Jakarta

16. Widodo Dwi Putro,. Kritik Terhadap Paradigma Positivisme Hukum, Genta Publishing, 2011, Jogjakarta 


\section{Journals :-}

1. Abdul Kholik. S. H. M.SI, Deddy Ismatullah. S. H. M.HUM \& Widayati. S. H. M.H, THE AUTHORITY DISPUTE OF STATE INSTITUTIONS IN THE IMPLEMENTATIONOF BICAMERAL SYSTEM IN INDONESIA (Study on Disputes between the House of Representatives (Dewanperwakilan Rakyat)-Republic of Indonesia and the House of Representatives-Republic of Indonesia in the Implementation of Legislative Function)International Journal of Political Science, Lawand International Relations (IJPSLIR)ISSN (P): 22788832; ISSN (E): 2278-8840Vol. 7, Issue 4, Aug 2017, Page. 37-58.

2. Elvira Fitriyani Pakpahan, Tommy Leonard, Heriyanti, LEGAL ANALYSIS ON BOND ISSUANCE OF THE RETAIL (ORI), International Journal of Business, Economics and Law, Vol. 11, Issue 4 (Dec.) ISSN 22891552,2016

3. Rahmat Basuki, Gunarto, Anis Masdurohatun, The ideal role of welfare state in the concept of health social insurance of BPJS based on justice values, International Journal of Multidisciplinary Research and DevelopmentOnline ISSN: 2349-4182, Print ISSN: 2349-5979, Impact Factor: RJIF 5.72www.allsubjectjournal.comVolume 4; Issue 7; July 2017; Page No. 183-190

\section{Interviews :-}

1. Interview with BUMN Office secretary, on 13 January 2017

2. Interview with BUMN Office secretary, on 23 February 2017 